\title{
ECO-EPIDEMIOLOGÍA DE ÁCAROS DEL GÉNERO ORNITHONYSSUS (ACARI: MESOSTIGMATA: MA- CRONYSSIDAE) EN AVES SILVESTRES Y GALLINAS PONEDORAS DE LA PROVINCIA DE SANTA
}

Sofía Irene Arce

sarce@santafe-conicet.gov.ar

Doctorado en Ciencias Biológicas

Director: Dr. Pablo Martín Beldomenico

Co-Director: Dr. Martín Aníbal Quiroga

Lugar de realización: Laboratorio, Cátedra y/o Departamento, Facultad, Universidad. Laboratorio de Ecología de Enfermedades, Instituto de Ciencias Veterinarias, UNL-CONICET. Fecha de la defensa: 11 de marzo de

\section{RESUMEN}

Los ácaros del género Ornithonyssus parasitan tanto a aves silvestres como a gallinas ponedoras. Diversos factores están asociados a su prevalencia e intensidad, tanto referidos a sus hospedadores como al ambiente. Estos ácaros, al ser hematófagos, pueden provocar diversas consecuencias negativas en sus hospedadores, como reducción del peso, abandono del nido, estrés, aumento de la mortalidad, entre otros. En los sistemas de producción avícola, estos ácaros pueden generar impactos negativos sobre las gallinas, por ejemplo reduciendo la tasa de puesta de huevos y generando un importante incremento en los costos. En estos sistemas, se ha sugerido que las aves silvestres podrían ser el origen de las infestaciones. El presente estudio busca analizar algunos de que podrían determinar el parasitismo de ácaros del género Ornithonyssus, tanto en aves silvestres como en gallinas ponedoras, además pretende analizar posibles efectos que estos ácaros pudieran tener en pichones de aves silvestres de la región. Además, se buscó determinar si las aves silvestres del ambiente de los establecimientos comerciales de gallinas ponedoras son hospedadores del mismo ácaro que infesta a las gallinas.

Por un lado, se llevó a cabo un experimento observacional longitudinal del ensamble de aves en dos sitios naturales a lo largo de dos años, lo cual se sumó a datos previos obtenidos por cuatro años, en los que se realizó un recuento de la abundancia de $O$. bursa sobre los pichones. Asimismo, se tomaron datos de sus hospedadores, del microhábitat del nido y del ambiente. Posteriormente, se realizó un análisis a diferentes niveles de organización biológica con el fin de determinar los factores asociados a su intensidad y prevalencia. Se halló que, a nivel de microhábitat del nido, la especie fue más importante que el material o tipo de nido para determinar los niveles de parasitismo. También estuvo involucrada la edad, cuyo efecto varió según la especie hospedadora, y el tamaño de la nidada, produciéndose un efecto dilución de la intensidad, de forma que en nidadas más grandes los pichones tuvieron menor intensidad de parasitismo. A un nivel superior, de la comunidad, los factores asociados fueron las temperaturas 
mínimas y máximas previas a la toma del dato, así como también la abundancia de nidos de Sicalis flaveola en el área. A nivel interanual, en un análisis preliminar se encontró que la abundancia de nido de S. flaveola tuvo una asociación positiva con la prevalencia e intensidad de $O$. bursa. Con respecto al efecto de los ácaros, solo se encontraron efectos en la mortalidad para tres de las especies bajo estudio, Pitangus sulphuratus, S. flaveola y Phacellodomus sibilatrix. Contrario a lo esperado, no hubo efectos en el desarrollo ni ganancia de peso en sus hospedadores.

Por otro lado, se realizó un estudio en establecimientos de gallinas ponedoras durante dos años, en donde se estimó la intensidad de infestación y la prevalencia de ácaros en las gallinas y se obtuvieron datos sobre la epidemiología de ácaros mesostigmátidos en aves silvestres del entorno. Se encontró que la prevalencia e intensidad del parasitismo fue menor en gallinas que contaban con la presencia de piojos y en las que la densidad de plumas en la zona donde se alojan los ácaros era reducida. La prevalencia también estuvo asociada a la cantidad de gallinas en las jaulas, y a la edad de las gallinas. Además, se colectaron dichos ácaros, y los presentes en nidos de aves silvestres con el fin de conocer sobre su epidemiología e identificarlos. Se halló que los ácaros presentes en las gallinas pertenecen a la especie Ornithonyssus sylviarum, mientras que dicha especie también es hallada en las aves silvestres adultas de los establecimientos, y en menor proporción, en sus pichones. Por medio de herramientas moleculares y morfométricas, tanto clásica como morfometría geométrica, no se hallaron diferencias entre los especímenes de $O$. sylviarum colectados de aves silvestres y gallinas ponedoras, lo que indicaría un posible intercambio del mismo entre ambos tipos de hospedadores.

\section{ABSTRACT}

\section{Eco-epidemiology of mites of the genus Ornithonyssus (Acari: Mesostigmata: Macronyssidae) in wild birds and laying hens from Santa Fe province}

Mites of the Ornithonyssus genus, which parasitize both wild birds and domestic fowl, are hematophagous. They may have a negative impact on their hosts, which becomes of economic importance in the poultry industry. To assess the drivers of parasitism of $O$. bursa, its abundance was determined on a sixyear longitudinal study carried out on a community of wild bird nestlings, considering data on its hosts and the surrounding environment at different levels of biological organization. At the microhabitat level, host species, nest type, age (varying between the different host species) and brood size affected mite levels of parasitism. At a higher level, factors associated were minimum and maximum temperature, and abundance of Sicalis flaveola nests in the area. The preliminary analysis at the interannual level found an association to the abundance of nests of S. flaveola. Only an effect on the mortality of three of the species under study was found (S. flaveola, Pitangus sulphuratus and Phacellodomus sibilatrix). A 
two-year long study in laying hens' farms was carried out, which determined that the abundance of mites had a negative association to the presence of lice, the feather density on the vent area, the number of hens in each cage and their age. Mites collected from hens and wild birds from the farms were identified, finding $O$. sylviarum present on both hosts. According to molecular and morphometrical analysis, no differences were found between the specimens of this species collected from different hosts. This would indicate a possible cross transmission between them. 